\title{
Nitrogen and Paraquat Saves Range Forage for Fall Grazing
}

\section{FORREST A. SNEVA}

Highlight: Chemical curing of $N$-fertilized crested wheatgrass was examined in 3 years. Both $N$ and paraquat, singly and in combination, significantly influenced various stand components. The combined treatments increased fall herbage yield $40 \%$, crude protein concentration $68 \%$, and crude protein yield $148 \%$ above that of the control.

Low gain of animals grazing poor quality forage on late summer-early fall ranges is a major problem on most semiarid rangelands. Sneva et al. (1972) have shown that yearling cattle gained $0.6 \mathrm{lb}$ more per day when grazing chemically cured crested wheatgrass (Agropyron desertorum) than yearling grazing naturally cured grass. Chemical curing of seeded ranges appears to have promise, but greater return could be realized if the production base could be increased.

Greatest return from nitrogen $(\mathrm{N})$ fertilization of seeded stands occurs in the more favorable moisture years and when grasses are permitted to reach maturity (Sneva, 1972), but the

The author is range scientist, Agricultural Research Service, U.S. Department of Agriculture, Burns, Oregon.

The study is a contribution from the Squaw Butte Experiment Station, Burns, Oregon. This Station is financed cooperatively by the Agr. Res. Serv., U.S. Dep. Agr., and the Oregon Agricultural Experiment Station, Oregon State University, Corvallis, (Ore. Agr. Exp. Sta., Technical Paper No. 3379.)

Manuscript received July 31, 1972. combination of $\mathrm{N}$ fertilizer and favorable moisture produce a low quality mature forage. Rarely is more low quality forage needed to balance the annual forage supply.

Greatest return from chemical curing should result when grasses are cured at a hay stage of maturity that maximizes total digestible nutrient production. This has generally been shown to occur prior to peak yield and in grasses is characterized by the early flower stage. Thus, chemical curing applied at that time would be expected to result in reduced herbage yield and response to $\mathrm{N}$.

This study examined the consequences of combining $\mathrm{N}$ fertilizer to increase the production base with chemical curing for retaining forage quality in crested wheatgrass.

\section{Procedure}

The Squaw Butte Experiment Station lies approximately 42 miles west of Burns, Ore. at an elevation of 4,600 ft. Areas now seeded to introduced grass species were once occupied by the big sagebrush-bunchgrass complex. This vegetative complex and associative soils have been studied and described by Eckert (1957). These soils are primarily sandy loams of basaltic origin and are often underlaid with a caliche hardpan at 12-24 inches. The annual precipitation is approximately 12 inches, most of which is received in the winter months. Summer and early fall is characterized by low precipitation. 
Four treatments, control, $\mathrm{N}$, paraquat ${ }^{1}$, and $\mathrm{N}$ plus paraquat were assigned to plots within each of five replications in a randomized block design experiment. Treatments were applied to plots $6 \times 20 \mathrm{ft}$ in each of the crop years 1969 , 1970, and 1971. Ammonium nitrate at $20 \mathrm{lb} /$ acre elemental $\mathrm{N}$ was applied to the surface each fall. Paraquat at $0.2 \mathrm{lb} /$ acre in 10 gal of water plus $X-77^{2}$ at $0.5 \%$ of total volume was applied with a 6-ft boom, bicycle sprayer. Dates of spray applications were June 20, 1969, June 18, 1970, and June 11, 1971.

Plots were sampled for herbage yields on or about August 1 of each year. An area $2 \times 12 \mathrm{ft}$ in the center of each treatment plot was harvested to ground level. Samples were oven dried in a forced air oven at $165^{\circ} \mathrm{F}$. They were subsequently weighed, ground through a Wiley mill, and a subsample retained in air-tight jars. The subsample was analyzed for Kjeldahl-N.

\section{Results and Discussion}

Crop-year precipitation (Sept-June, inc.) in each year varied only slightly from the median amount of 11.0 inches (Table 1). Exceptionally heavy rains totaling 2.72 inches fell in August, 1968, following a record drought year and account for the significantly $(P<0.05)$ greater herbage yield in 1969. This greater yield in 1969 was primarily responsible (through dilution) for the low crude protein concentrations in that year. Possibly, the earlier curing treatment (7-9 days) in 1971 accounts for the significantly higher mean crude protein concentrations in that year.

Table 1. Average herbage yield $\left(\mathrm{g} / 24 \mathrm{ft}^{2}\right)$, herbage crude protein concentration $(\%)$, crude protein yield $\left(\mathrm{g} / 24 \mathrm{ft}^{2}\right)$, and crop-year precipitation (inches) for each year.

\begin{tabular}{lrrr}
\hline \hline & \multicolumn{3}{c}{ Year } \\
\cline { 2 - 4 } \multicolumn{1}{c}{ Item } & 1969 & 1970 & 1971 \\
\hline Herbage yield & $2096^{\mathrm{c}}$ & $918^{\mathrm{a}}$ & $1056^{\mathrm{b}}$ \\
Crude protein conc. & $4.7^{\mathrm{a}}$ & $5.1^{\mathrm{b}}$ & $6.2^{\mathrm{c}}$ \\
Crude protein yield & $23.3^{\mathrm{c}}$ & $11.3^{\mathrm{a}}$ & $14.5^{\mathrm{b}}$ \\
Precipitation $^{2}$ & 10.68 & 9.87 & 11.43 \\
\hline
\end{tabular}

${ }^{1}$ Statistical significance at $P<0.05$ denoted by unlike superscripts within row comparison.

${ }^{2}$ Crop-year (Sept. 1 to June 30 , inc.).

Both $\mathrm{N}$ fertilizer and paraquat, singly and in combination, significantly influenced herbage yield $(P<0.05)$ (Table 2$)$. Yield of fertilized grasses was $80 \%$ greater than that of unfertilized grasses. Paraquat, whether alone or in combination with $\mathrm{N}$, stopped growth when grasses had obtained about $78 \%$ of the year's production. With the combination treatment the net result was an increase in herbage yield of $40 \%$.

Twenty pounds per acre of $\mathrm{N}$ did not significantly $(P>0.05)$ increase the crude protein concentration of fall-harvested crested wheatgrass (Table 2). Significantly higher $(P<0.05)$ crude protein concentration was present in harvested grass receiving paraquat treatment than in either fertilized or unfertilized grass.

While the total forage crop is important, the yield of high quality forage during the late summer early fall grazing period is of particular concern. Both paraquat and $\mathrm{N}$ and the combining of these two treatments significantly increased $(P<0.05)$ the crude protein yield (Table 2$)$. Combining the two treatments increased the crude protein yield 2.5 times over the control plots. The difference in digestible crude protein yield betwcen naturally and chemically cured forage as a feed

\footnotetext{
${ }^{1}$ Paraquat (1,1'dimethyl-4,4'-bipyridinuim ion) has not been registered by the U.S. Environmental Protection Agency for this use.

${ }^{2}$ The use of a trade name does not imply its indorsement above that of similar products.
}

Table 2. Average herbage yield $\left(\mathrm{g} / 24 \mathrm{ft}^{2}\right)$, crude protein concentrations (\%), and crude protein yield $\left(\mathrm{g} / 24 \mathrm{ft}^{2}\right)$ as influenced by treatments. ${ }^{1}$

\begin{tabular}{lcccc}
\hline \hline Constituent & Control & Paraquat & Nitrogen & Paraquat $+\mathrm{N}$ \\
\hline Herbage yield & $818^{\mathrm{b}}$ & $633^{\mathrm{a}}$ & $1471^{\mathrm{d}}$ & $1148^{\mathrm{c}}$ \\
Crude protein conc. & $3.8^{\mathrm{a}}$ & $7.6^{\mathrm{c}}$ & $3.6^{\mathrm{a}}$ & $6.4^{\mathrm{b}}$ \\
Crude protein yield & $9.5^{\mathrm{a}}$ & $15.2^{\mathrm{b}}$ & $17.0^{\mathrm{b}}$ & $23.6^{\mathrm{c}}$ \\
\hline
\end{tabular}

${ }^{1}$ Statistical significance $(P<0.05)$ denoted by unlike superscripts within row comparisons.

for grazing animals is actually greater than appears from Table 2. Wallace et al. (1966) reported higher digestion coefficients of most nutrients in chemically than in naturally cured grass forage by both in vitro and in vivo methods.

Crude protein yield, as influenced by treatment, varied significantly $(P<0.05)$ by years. This interaction is shown in Figure 1. The interaction resulted from high crude protein yield in both fertilized and unfertilized grasses treated with paraquat in 1969. It is believed due to a carryover of soil $\mathrm{N}$ not utilized in the extreme drought year of 1968 and subsequently influencing yields in 1969. Carry over of $\mathrm{N}$ from 1968 is also substantiated by a lower yield response to applied $\mathrm{N}$ in 1969 (63\% yield increase) than in the other 2 years (91 and $105 \%$ yicld increasc).

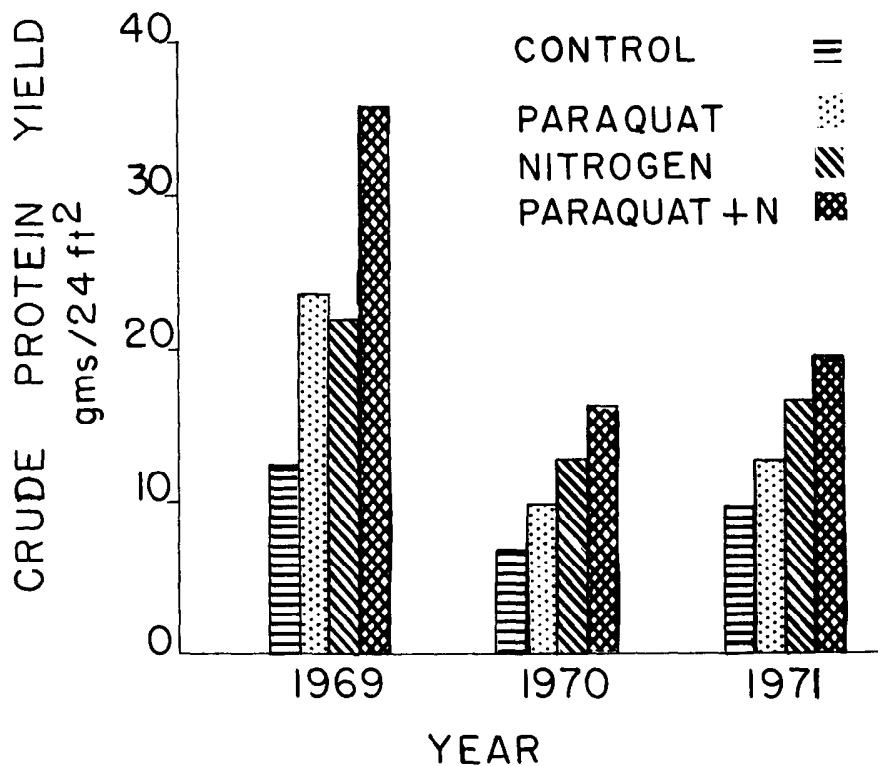

Fig. 1. Crude protein yield of crested wheatgrass as influenced by nitrogen fertilization and paraquat.

It is inferred from the results that $\mathrm{N}$ fertilizer for increasing yield and paraquat for curing the fertilized grass can be combined for increasing the yield and quality of late season forage. Should paraquat be cleared for this use, or a similar acting cleared chemical be found, the combination treatment offers an encouraging opportunity.

\section{Literature Cited}

Eckert, Richard Edgar. 1957. Vegetation-soil relationships in some Artemisia types in northern Harney and Lake Counties, Oregon. PhD Thesis. Oregon State Univ. 208 p.

Sneva, Forrest A., R. J. Raleigh, and H. A. Turner. 1973. Paraquatcured herbage for late season grazing. J. Anim. Sci. 36:107-113.

Sneva, Forrest A. 1972. Crested wheatgrass response to nitrogen and clipping. J. Range Manage. 26(1):47-49.

Wallace, Joe D., F. A. Sneva, R. J. Raleigh, and C. B. Rumburg. 1966. Digestibility of chemically cured range forage. Proc. West. Sec. Am. Soc. Anim. Sci. 17:385-390. 